\title{
Production Process of Front Lights on Anoa 2 6x6 Special Vehicles at PT. Pindad (Persero)
}

\author{
Abdul Khair Junaidi ${ }^{a, *}$, Nandha Syamza ${ }^{b}$, Tri Subagyo ${ }^{c}$ \\ a) Industrial Engineering of Sekolah Tinggi Teknologi Pelalawan, Riau, Indonesia \\ b) Department of Mechanical Engineering, Faculty of Engineering, Universitas Riau, Indonesia \\ c) PT. PINDAD, Indonesia
}

*Corresponding author: junaidiperu@yahoo.com; nandha.syamza@gmail.com

\section{Paper History}

Received: 06-June-2020

Received in revised form: 21-February-2021

Accepted: 30-March-2021

\begin{abstract}
The headlights on Anoa 2 6x6 special vehicles are used for street lighting for anoa tanks at night. The purpose of this study was discussed the steps of production process of the Anoa $26 \times 6$ headlights in PT. Pindad. The headlight component was made in several manufacturing processes that were carried out. It consists of many parts, which a variety of production machines for the manufacture of each part. The manufacturing of the headlight components using machining processes such as laser cutting, welding and drilling. The type of material used for the manufacture of the headlights and parts that was Aluminum Alloy 2044 and Steel ST-37. The result components were made the headlight frame, BT protectors, the front, side, and rear components.
\end{abstract}

KEY WORDS: Headlights, Anoa 6x6, Production Process.

\subsection{INTRODUCTION}

In the production process carried out, there are several factors that influence including the availability of facilities (machines) that are reliable. Because, if a machine is damaged or disrupted, then the production process would be disrupted, and result in failure to produce products or the emergence of defective products and product delays to the consumer's hand or customer. Therefore, it is necessary to have production planning for job-sequences to done the product [1].

The production process flow such as the flow shop is a series of jobs started processing at starting machine, proceed through several intermediaries machine, and is completed on the last machine. The production process flow of the jobsshop is processed on machines in any order a job, which a cross-production sequence, machines, and equipment are arranged based on the type of product work [2,3]. The characteristics of production using a job shop are: the number of semi-finished products (work in process) tends to be larger; requires detailed production planning and control, production and material handling equipment can be adjusted and modified to handle a wide variety of products [4]. The production that requires a high variety of products is best adopted a job-shop system $[5,6]$.

PT. Pindad (Persero) is a state-owned business entity located in Bandung, West Java, which manufactures various kinds of heavy equipment for military and non-military purposes. PT. Pindad (Persero) is a company that uses the job order system in the production process. The job order is a production method in a company on the basis of an order to make a product [7]. One of products are produced in PT. Pindad of the Anoa $26 \times 6$ special vehicles.

The Anoa 2 6x6 products consist of many parts to be manufactured. One part of this product is the headlights. The headlights are a component that functions as a road lighting device at night. Several studies on vehicle headlight systems such as: adaptive high beam assist - vehicle headlights are detected using a mounted camera [8]. The headlight is controlled by a sensor to regulation using camera, which a mechanical block ensures that the oncoming vehicle is not affected [8]. More, the control of vehicle headlights uses a light sensor [9]. The system is a reading of the sensor exceeds the threshold values, the vehicle own headlights are turned off [9]. Tripathy et al [10] developed a wireless solution to control headlight intensity.

The process of making the Anoa 26x6 headlight components requires several stages on the production processes. The processes of making headlight components is carried out in various places such as fabrication section to manufacturing of the headlight frames, BT protective frames, 
headlight vents and ventilation cover plates. In addition, in the fabrication section has also the casting unit. In this casting unit, process of making the part of headlight was done. This paper is aimed to study the steps of production process of the headlights for Anoa 2 6x6 special vehicles in PT. Pindad.

\subsection{METODOLOGI}

This study was employed the qualitative method, which descriptive analysis approach. A production process requires high accuracy to produce high quality of the headlights according to the standards set by PT. Pindad. If any of the headlight components were not up to standard, it would be repaired or repeat the manufacturing process from scratch. This can cause losses in terms of time and material, so, a planning process for the manufacture of parts is needed to effective and efficient in production activities [11].

The production activities the headlights were carried out starting from the design, the production process and assembly of Anoa $26 \times 6$ special vehicles. The headlight is an essential component in special vehicles Anoa 2 6x6 at PT. Pindad. These headlights consist of 2 pieces for one anoa $26 \times 6$, was located at the front of the vehicle. The headlamps consist of 5 components namely: headlight frame, BT protector, ventilation, ventilation cover plate and headlamp housing. The component parts of the headlight frame, BT protectors were carried out or processed in the fabrication section. Whilst, the front, side and rear components were processed in the cast forging section by printing and machining processes, which were the laser cutting, drilling, welding and bending machine.

The headlights production process used several production machines. The production machine is useful to simplify all production processes including to handle interior and exterior accessories components of Anoa $26 \times 6$. In the production machines are also needed machines for cutting, bending, treating and connecting metal. The example machines were used to make the headlight components of Anoa $26 \times 6$ can be seen in Figure 1-3.

\section{Lasser Cutting Machine}

The lasser cutting machine is used in the process of cutting various types of metals or plates or other materials with a good degree of accuracy. Plate cutting done with a plasma cutter produces much smoother results. The lasser cutting machine is presented Figure 1.

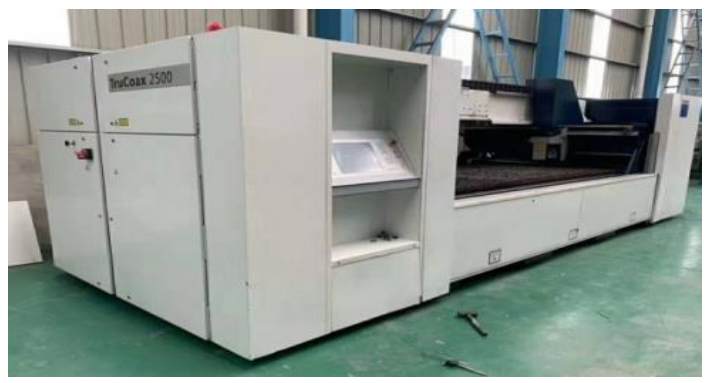

Figure 1: Lasser Cutting Machine

\section{Welding Machine}

The welding machine is one of the metal joining techniques by melting some of the parent metal and filler metal with or without pressure. The welding machine used in
PT. Pindad is made by WIM namely MIG ECO $350 \mathrm{~F}$ welding machine (Figure 2). This welding machine is used during the welding assembly processes.

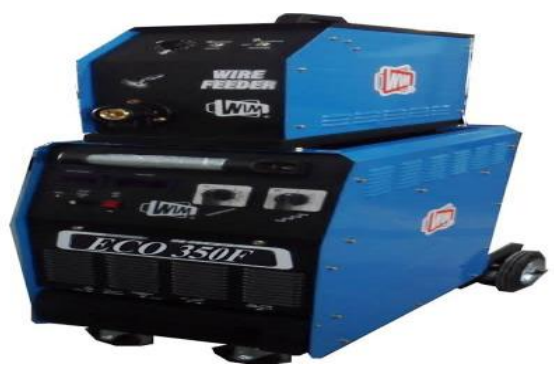

Figure 2: Welding Machine MIG ECO 350F

\section{Grinding Machine}

The grinding machine is one of the machine tools to grind or cut the work-pieces with specific goals or needs. The working principle of a grinding machine is a rotating grinding stone in contact with the work-piece resulting in erosion, sharpening, sharpening or cutting. The grinding machine can be seen in Figure 3.

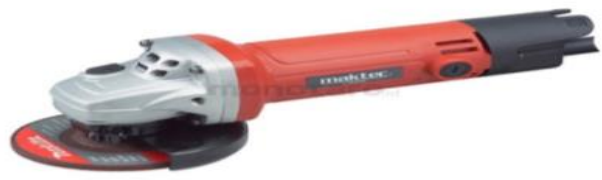

Figure 3: Grinding Machine

There were 3 materials used to make the headlights in the production process of Anoa 2 6x6, namely:

a. Aluminum alloy 2044

Aluminum Alloy 2044 was developed specifically for the electronics and automotive industries for its excellent engine characteristics and mechanical properties.

b. Steel ST-37

Low carbon steel (ST 37) has a carbon content of less than $0.3 \%$. This steel is often used also for machine constructions.

c. Bullet proof steel

Special hardened steel plates are used to protect the fortress or vehicles from enemy fire. Homogeneous steel that is rolled strong, hard, and tough (does not break when hit with a fast and hard punch).

\subsection{RESULT AND DISCUSSION}

The headlights were components on special vehicles of the Anoa 2 6x6, which function as street lights at night. The process of making Anoa 2 6x6 Armoured Personnel Carrier (APC) headlight components required several machines and equipments.

The stages of the production process for making headlights on Anoa $26 \times 6$ special vehicles such as: the preparation for safety equipments, selection of the material, cutting material, material forming, welding, the pre-assembly process and final product. The headlamps components was made headlight frame, BT protector, ventilation headlight, ventilation of cover plate and headlamp housing. 


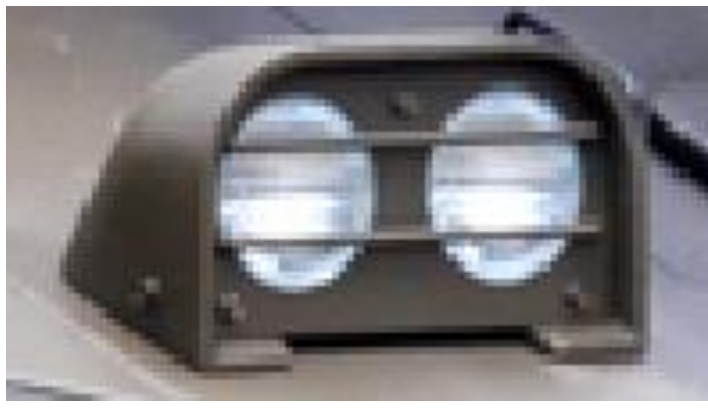

Figure 4: The Headlight

The production process stages and job-sheet for headlight frame can be seen in Figure 5. The headlight frame was made from the steel material of ST-37. The headlight frame has the dimensions of $264 \times 140 \times 3 \mathrm{~mm}$. The production process on the headlight frame used a laser cutting machine, grinding machine and drilling machine. In the circle the lights were cut with a $74 \mathrm{~mm}$ radius circle.

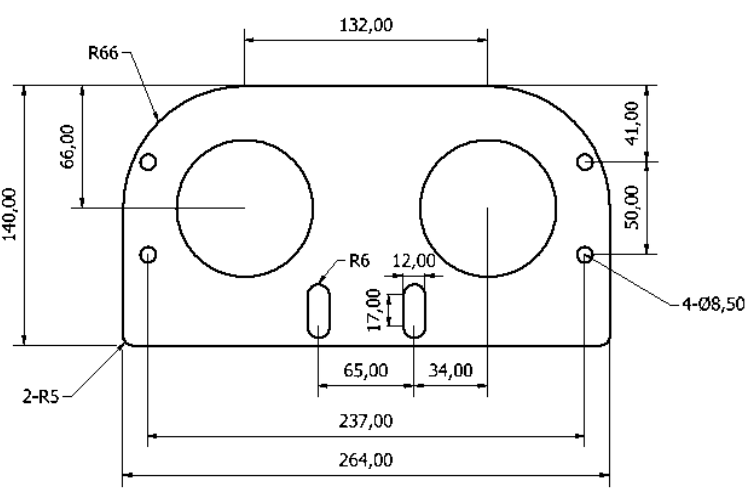

Figure 5: The Headlight Frame

On the side of the headlights used the 2044 Aluminum Alloy material with a dimension of $162 \times 164 \times 8 \mathrm{~mm}$. In the manufacturing process carried out on the cast forging by using finished molds. At the front of the headlights used the 2044 Aluminum Alloy material with a dimension of 280x140x8 $\mathrm{mm}$. In the manufacturing process that was carried out in the fabrication section. More, BT protective headlight frame used ST-37 steel plate material with a material thickness of $8 \mathrm{~mm}$, with a length of $237 \mathrm{~mm}$. This BT protector functions was as a protective frame for the headlight house.

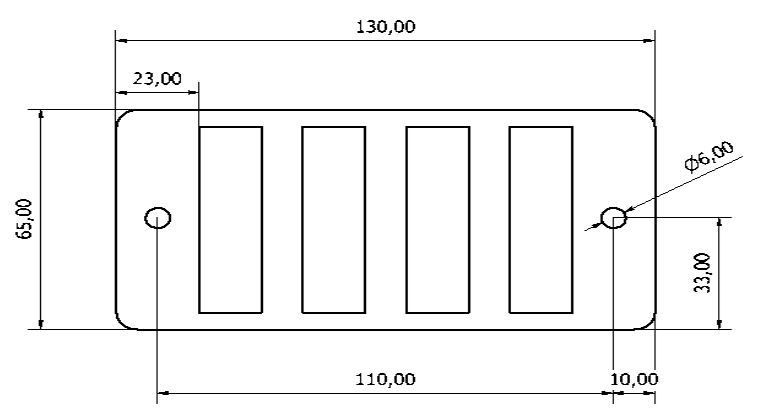

Figure 9: Ventilation of Headlight

The manufacturing of ventilation of headlights used the Aluminum Alloy 2044 plate material with a dimension of
$130 \times 65 \times 8 \mathrm{~mm}$. The process of making the headlights was done in the fabrication section. The process of making ventilation holes was done in the fabrication section by using lasser cutting and making 2 small holes that was done by drilling machine. Lastly, the manufacturing of ventilation cover plate used steel material ST-37 with dimension of $84 \times 54 \times 8 \mathrm{~mm}$. The manufacturing process used a lasser cutting and bending machine. The plates are bent by a CNC bending machine with bend sizes of $68^{\circ}$ and $22^{\circ}$.

\subsection{CONCLUSION}

This study was performed in a production unit to manufacture headlight of Anoa $26 \times 6$ special vehicles at PT. Pindad, Indonesia. The job was organised as a job-shop. Based on the results of this study was obtained the process of making the Anoa 2 6x6 headlight components, which was carried out in the fabrication and forging unit areas. The component parts of the headlight frame, BT protectors were carried out or processed in the fabrication section. The front, side, and rear components were processed in the cast forging section. The production processes used machining processes such as laser cutting, drilling, welding, bending and grinding machine.

\section{ACKNOWLEDGEMENTS}

The author would like to thank PT. PINDAD (Persero), Indonesia, which has supported this research as practical work in 2020 .

\subsection{REFERENCE}

[1] Vincent, O., Ijedinma, N., Ugwuegbu, C. and Onyemachi, S. (2018). Production planning and organizational effectiveness, Strategic Journal of Business and Social Science, Vol.1, pp:1-28.

[2] Parveen, S. and Ullah, H. (2010). Review on job-shop and flow shop scheduling using multicriteria decision making, Journal of Mechanical Engineering, Vol.41, No.2, pp:130-146.

[3] Panneerselvam, R. (2006). Production and Operation Management. Prentice Hall, New Delhi, India.

[4] Dinis-Carvalho, José \& Alves, Anabela \& Sousa, Rui. (2014). Moving from job-shop to production cells without losing flexibility: A case study from the wooden frames industry, South African Journal of Industrial Engineering, Vol.25, pp: 212-225.

[5] Heizer, J. and Render, B. (2013). Operations Management. 11th edition. Prentice Hall.

[6] Zhang, J., Ding, G., Zou, Y., Qin, S. and Fu, J. (2019). Review of job shop scheduling research and its new perspectives under Industry 4.0, Journal of Intelligent Manufacturing, Vol.30, pp:1809-1830.

[7] Miltenburg, J. (2001). U-shaped production lines: a review of theory and practice, International Journal of Production Economics, Vol.70, pp: 201-214.

[8] Chen, Y.L., Chiang, H.H., Chiang, C.Y., Liu, C.M., Yuan, S.M. and Wang, J.H. (2012). A vision-based driver night-time assistance and surveillance system based on intelligent image sensing techniques and a heterogamous dual-core embedded system architecture, Sensors (Basel), Vol.12, No.3, pp:2373-2399. 
[9] Zhang, W., Wu, Q.M.J., Wang, G. and You, X. (2012). Tracking and pairing vehicle headlight in night scenes, IEEE Transactions on Intelligent Transportation Systems, Vol.13, No.1.

[10] Tripathy, A.K., Kayande, D., George, J., John, J. and Jose, B. (2015). Wi lights - a wireless solution to control headlight intensity, International Conference on Technologies for Sustainable Development (ICTSD2015), Feb. 04-06, 2015, Mumbai, India.

[11] Kiran, D.R. (2019). Chapter 1 - Elements of production planning and control, in Production Planning and Control. Butterworth-Heinemann. 